\title{
Analysing the Power of the European Union's Diplomatic Service: Do the E U Member States Control the European External Action Service?
}

\author{
Hrant Kostanyan
}

Centre for European Policy Studies (CEPS), 1000 Brussels, Belgium hrant.kostanyan@ceps.eu

Received: 17 November 2014; revised: 25 August 2015; accepted: 27 September 2015

\section{Summary}

By applying the rational choice principal-agent model, this article examines the European Union member states' principal control of the European External Action Service (EEAS) agent. More specifically, the article applies mechanisms of agency monitoring, control and sanctions that are inherent in the principal-agent model to analyse the establishment and functioning of the EEAs. These mechanisms aim to ensure the EEAs's compliance with its mandate, thereby curtailing its ability to pursue own objectives that are independent from the principal. The findings reveal that the EEAS is tightly controlled by the EU member states. Moreover the European Commission has tools to exercise horizontal checks vis-à-vis the EEAs. The application of the principal-agent model to control the EEAS is not without its limits. The model falls short of conceptualizing the role of the European Parliament, which remains an outlier to this model.

\section{Keywords}

European Union (EU) - EU foreign policy - European External Action Service (EEAS) - Lisbon Treaty - principal-agent

\section{Introduction}

The European Union's (EU) incoherent and ineffective response to international developments so far this century has highlighted the need to improve 
the Union's external action. A major attempt to address the shortcomings took shape in the framework of the European Convention (2002-2003), where the EU member states and supranational institutions laid the foundation for the institutional modifications that were intended to invigorate EU foreign policy. The European Convention proposed several novelties, such as the creation of the posts of the President of the European Council and the High Representative of the Union for Foreign Affairs and Security Policy, who will also hold the position of the European Commission's Vice-President (HR/vP). The proposal to establish the European External Action Service (EEAS) was the centrepiece of the EU's revamped foreign policy architecture.

After the failure of the ratification process of the Constitutional Treaty (2005), the actual establishment of the EEAS was postponed until the enactment of the Lisbon Treaty (2009). Analysis of the negotiation process reveals that the EEAS is the product of a compromise between the EU member states, the Commission and the European Parliament. The outcome of the compromise is evident in the EEAs's suigeneris nature of being neither a supranational nor an intergovernmental body: having unique linkages with the EU member states; being somewhat accountable to the European Parliament; and receiving a requirement to cooperate with the European Commission. Not only does the EEAS connect the rest of the EU's external actors through assisting, supporting and cooperating, it also employs its own staff members from the Council Secretariat, the Commission and the EU member states' diplomatic services. ${ }^{1}$

Although the EEAS was built on the EU's existing structures, its hybrid institutional composition is a new experiment for the EU, which already had a very sophisticated institutional architecture. It is therefore puzzling that rather than shift power to the Council Presidency or the Council Secretariat, over which the member states have more control, ${ }^{2}$ the 'non-integrationist' member states agreed to delegate powers to the EEAS agent, which has a very complex structure, is placed outside of the Council, and operates in both communitarian and intergovernmental decision-making modes. The establishment of a new agent with unprecedented characteristics raises questions about whether the member states that delegated the EEAs's discretion to manage the EU's external action on their behalf are indeed able to monitor and control effectively the actions of the EEAs. By applying the principal-agent model, this article examines the member states' principal control of the EEAS agent.

1 Art. 27(3) TEU.

2 See Hylke Dijkstra, 'Explaining Variation in the Role of the Eu Council Secretariat in First and Second Pillar Policy-making', Journal of European Public Policy, vol. 17, no. 4 (2010), pp. $5^{27-544 .}$ 
In order to assess whether the member states put in place effective control mechanisms to tie the EEAS to its mandate, this article relies on qualitative methods and a triangulation of data collected from multiple sources, including legal documents, semi-confidential papers, journalistic articles, secondary literature and 68 off-the-record interviews that were conducted with key actors to gain insight into the behind-the-scenes struggles. Those interviewed are, inter alia, staff members of the EEAS, members of the EU member states' permanent representations to the EU, officials of the European Commission's relevant Directorates-General (DGs) and key members of the European Parliament.

The EEAS's innovative organizational structure has attracted the increasing attention of research communities. Scholars applied a neo-realist interpretation ${ }^{3}$ and argued for the need to go beyond intergovernmentalist explanations ${ }^{4}$ when analysing the EEAS. Competing theoretical approaches have also been applied to explain the attitudes of EEAS staff towards the process of setting up the EEAS, as well as towards the service's structure and composition. ${ }^{5}$ A few studies have applied the principle-agent model to assess the EEAs's discretion in specific areas of performance, namely in the Common Foreign and Security Policy (CFSP), the Common Security and Defence Policy (CSDP), development ${ }^{6}$ and the Eastern Partnership. ${ }^{7}$ Building on the existing literature and going beyond the analysis of specific areas of the EEAs's performance, this article makes both a theoretical and empirical contribution to the literature. Theoretically, the analysis composes a principal-agent account that serves as a foundation for the systematic examination of the control of the EEAS. Empirically, the article contributes not only to our understanding of the

3 Michael Kluth and Jess Pilegaard, 'The Making of the EU's External Action Service: A Neorealist Interpretation', European Foreign Affairs Review, vol. 17, no. 2 (2012), pp. 303-322.

4 Federica Bicchi, 'The EU as a Community of Practice: Foreign Policy Communications in the COREu Network', Journal of European Public Policy, vol. 18, no. 8 (2011), pp. 1115-1122.

5 Ana E. Juncos and Karolina Pomorska, 'In the Face of Adversity: Explaining the Attitudes of E EAS Officials vis-à-vis the New Service',Journal of European Public Policy, vol. 20, no. 9 (2013), pp. 1332-1349.

6 Mark Furness, 'Who Controls the European External Action Service? Agent Autonomy in EU External Policy', European Foreign Affairs Review, vol. 18, no. 1 (2013), pp. 103-126.

7 Hrant Kostanyan and Jan Orbie, 'The EEAs's Discretionary Power within the Eastern Partnership: In Search of the Highest Possible Denominator', Journal of Southeast European and Black Sea Studies, vol. 13, no. 1 (2013), pp. 45-62; and Hrant Kostanyan, 'Examining the Discretion of the EEAS: What Power to Act in EU-Moldova Association Agreement?', The European Foreign Affairs Review, vol. 19, no. 3 (2014), pp. 373-392. 
establishment of the EEAs's organization and functioning, but also adds to our knowledge of the post-Lisbon EU foreign policy architecture in general.

The article finds that the EU member states closely monitor and control the EEAS through so-called 'police patrol', which is a direct monitoring of an agent by a principal. Moreover, the Commission has tools for 'horizontal checks' of the EEAS, which is a mechanism of an indirect control. The European Parliament, which played an important role in the establishment process of the EEAS, is an outlier to the principal-agent model.

After this introductory section, the article presents the principal-agent framework. Analysis in the third section focuses on the ex-ante control of the EEAS. The fourth section details ex-post police patrol and horizontal checkmonitoring and control of the EEAS agent. Fifth, the article identifies the possibility of sanctioning the EEAS through staffing, financing and agency revision. The final section sums up and discusses the main findings.

\section{The Principal-Agent Model and Control of the EEAS}

A principal-agent relationship is 'created when one party, the principal, enters into a contractual agreement with a second part, the agent, and delegates responsibility to the latter for carrying out a function or set of tasks on the principal's behalf'. ${ }^{8}$ Following Hawkins et al., the 'principal' is defined as the actor capable of both granting and withdrawing power. ${ }^{9}$ In the application of the model, this article considers the EU member states as sole principal, since only they can delegate power to the EEAS agent to act on their behalf. Unlike the vertical and hierarchical relations between the EU member states' principal and the EEAS agent, the Commission's relations with the EEAS are horizontal and non-hierarchical. However, applying the principal-agent model to the control of the EEAS is not without limits, especially when conceptualizing the role of the European Parliament, which remains an outlier to the model.

8 Hussein Kassim and Anand Menon, 'The Principal-Agent Approach and the Study of the European Union: Promise Unfulfilled?', Journal of European Public Policy, vol. 10, no. 1 (2003), p. 125 .

9 Darren G Hawkins, David A. Lake, Daniel L. Nielson and Michael J. Tierney, 'Delegation under Anarchy: States, International Organizations and Principal-Agent Theory', in Darren G. Hawkins, David A. Lake, Daniel L. Nielson and Michael J. Tierney (eds), Delegation and Agency in International Organizations (New York: Cambridge University Press, 2006), pp. 3-39. 
The principal-agent model assumes that a principal delegates its power to an agent to maximize the possibility of achieving the pursued objectives or to ensure the credibility of the principal's commitment. The agent, however, is perceived as 'self-interest seeking with guile'10 that is able to develop its own preferences over time and to strive for their realization. Therefore, the principal is faced with the challenge of obtaining 'perfect compliance from agents'.11 The principal's willingness to transfer power to a given agent is thus conditioned by its ability to control the agent. ${ }^{12}$

The principal sets control mechanisms that aim to tie the agent to the granted mandate and thus to minimize the agent's ability to pursue its own objectives independent of the principal. Through control mechanisms, the principal retains the ability to 'mitigate conflicts of interest through the careful design of incentive contracts but can rarely control agents perfectly'.13 Paradoxically, containing agency losses might require 'undertaking measures that are themselves costly'14 and can therefore undo the anticipated benefits of delegation. The principal thus seeks to strike a balance between the control and autonomy of an agent in a way that would allow the agent to perform its mandate effectively.

This study assembles the control mechanisms of the EEAS in ex-ante - that is, before establishment of the EEAS - and ex-post — that is, after establishment of the EEAS - groups, continued by its sanctioning through staffing, budget and revision of the mandate. Ex-ante administrative procedures intend to define the scope of agency activities, outline the legal instruments (for example, regulation and economic incentives) and set the procedures that an agent is required to follow in performing delegated functions. ${ }^{15}$ Administrative requirements are useful, in particular for the purpose of combating infor-

10 Oliver E. Williamson, The Economic Institutions of Capitalism: Firms, Markets, Relational Contracting (London: Macmillan, 1985), p. 47.

11 Michelle Egan, 'Regulatory Strategies, Delegation and European Market Integration', Journal of European Public Policy, vol. 5 no. 3 (1998), p. 489.

12 Bart Kerremans, 'What Went Wrong in Cancun? A Principal-Agent View on the EU's Rationale towards the Doha Development Round', European Foreign Affairs Review, vol. 9, no. 3 (2004), p. 366.

13 David Epstein and Sharyn O'Halloran, Delegating Powers: A Transaction Cost Politics Approach to Policy Making under Separate Powers (Cambridge: Cambridge University Press, 1999), p. 28.

14 Roderick Kiewiet and Mathew McCubbins, The Logic of Delegation: Congressional Parties and the Appropriation Process (Chicago, IL: University of Chicago Press, 1991), p. 27.

15 Mark A. Pollack, The Engines of European Integration: Delegation, Agency, and Agenda Setting in the EU (Oxford: Oxford University Press, 2003), p. 40. 
mational asymmetries, but are not sufficient for the effective control of agency activities.

The principal therefore resorts to ex-post oversight procedures to monitor and control the agency's activity. ${ }^{16}$ So-called 'police patrol' by the EU memberstate principals provides the means for direct monitoring of the behaviour of the EEAS agent. Moreover, the Commission has tools to exercise horizontal checks vis-à-vis the EEAS. In addition, the EEAS is accountable to the European Parliament in a number of areas (such as budget and staff). The information collected through monitoring is particularly valuable if used to reward or 'sanction' the agent in a manner that incentivizes the agent 'to comply with the principal's objectives and intentions.' ${ }^{17}$ The principals may sanction their agent for non-compliance with the stipulated mandate, specifically through staffing, financing and revision of the mandate.

\section{Ex-Ante Control of the EEAS}

The European Convention (2002-2003) was the forum for the conception of the EEAS. The Convention's Working Group on External Action was the first to put forward a blueprint for the establishment and functioning of the EEAS and the post of its head - the HR/VP. In its final report, the Convention's Working Group suggested a number of scenarios for the reconstruction of EU external action. The first scenario proposed measures that would strengthen the role of the HR and create synergies between the competences of the HR and the DG External Relations (Relex) Commissioner, while keeping the two functions separate. Another option was to merge the functions of the HR and the Relex Commissioner and to bring the new HR under the direct authority of the President of the European Council. The report also put forward the option of a full merger of the HR with the Commission, while safeguarding the specificity of the European Security and Defence Policy (ESDP, now CSDP) decision-making. ${ }^{18}$ The latter option, in particular, was supported by the European Commission and the European Parliament, ${ }^{19}$ since it was in line with the interest of the institutions to strengthen the supranational character

\footnotetext{
16 Pollack, The Engines of European Integration, p. 42.

17 Egan, 'Regulatory Strategies, Delegation and European Market Integration', p. 489.

18 European Convention, 'Final Report of Working Group viI on External Action', 2002, CONV 459/02, p. 19 .

19 European Convention, 'Letter from Mr Giuliano Amato, on behalf of the Party of European Socialists, Mr Elmar Brok on behalf of the European People's Party and Mr Andrew Duff,
} 
of EU foreign policy and thus expand their respective competences. A group of small EU member states such as Finland and the Benelux countries also agreed with transferring foreign policy to the European Commission, while keeping separate the decision-making on the CFSP. Conversely, bigger member states such as the United Kingdom and France were categorically against the move. ${ }^{20}$

The eventual establishment of the EEAS and HR/VP was the result of a compromise that had already been proposed by the Convention between two major camps of the EU member states. According to this option, the new HR/VP combines his/her predecessor's and the Relex Commissioner's mandates and is supported by the EEAS, which is neither part of the Commission nor part of the Council Secretariat. On the one hand, the compromise on the EEAS made it possible for the member states that were against the integration of EU foreign policy to maintain their control over the EU's external action. If the EEAS is to be integrated into the European Commission, EU foreign policy would become more communitarian, giving the EU's supranational institutions a greater say in decision-making at the expense of the EU member states' control. Starting from a neo-realist interpretation, Michael Kluth and Jess Pilegaard argue that the United Kingdom and France compromised on the establishment of the EEAS to compensate for their decreasing global influence. ${ }^{21}$ London and Paris expected the EEAs to act in line with their foreign offices because of their dominance. On the other hand, the EEAS was not merged with the Council's structures, where the EU member states have even greater control, ${ }^{22}$ thus satisfying the pro-integration member states and institutions.

As in the pre-Lisbon Treaty stage, the member states maintain tighter and more direct control in areas where the EU conducts its CFSP and CSDP than over issues beyond the CFSP. ${ }^{23}$ Although the EU acquired a 'single legal personality', the so-called communitarian and intergovernmental areas of EU

on behalf of the European Liberal, Democratic and Reform Party', 2003, CONV 829/03, pp. 17-18.

20 Niklas Helwig, 'Eu Foreign Policy and the High Representative's Capability-Expectations Gap - a Question of Political Will', European Foreign Affairs Review, vol. 18, no. 2 (2013), pp. 235-254; and European Convention, 'The Comments by Mr Peter Hain to the Preliminary Draft Final Report of Working Group VII on External Action', 2002, WD 021-WGVII.

21 Kluth and Pilegaard, 'The Making of the Eu's External Action Service'.

22 See Dijkstra, 'Explaining Variation in the Role of the Eu Council Secretariat in First and Second Pillar Policy-making', pp. 527-544.

23 Hans Merket, 'The European External Action Service and the Nexus between CFSP/CsDP and Development Cooperation', European Foreign Affairs Review, vol. 17, no. 4 (2012), pp. $625-652$. 
externalactionpreservetheirseparatedecision-makingprocedures. ${ }^{24}$ Therefore, decision-making in the area of the CFSP has formally remained intergovernmental. In practice, this division is visible in the structure of the EEAS, where units dealing with the CSDP are isolated from the geographical units. ${ }^{25}$ Distinctive control mechanisms for each of these areas govern the decisionmaking processes and are therefore $e x$-ante transferred into respective functions covered by the EEAS.

Moreover, in order to ensure the continuation of the existing EU member states' competences in the CFSP, the member states attached provisions to the 'Final Act' of the Lisbon Treaty at the 2007 Intergovernmental Conference (IGC). The declaration states that the establishment of the new HR post and the EEAS shall not affect member states' foreign policy, their national representation in third countries, or international organizations. Moreover, the provision adds that CFSP decision-making shall not prejudice member states' security policy.

Although the Lisbon Treaty conferred on the HR/VP the right to make proposals on the establishment of the EEAS, on 1 December 2009 the European Council endorsed the proposal prepared by the Council's rotating presidency before the HR/vP (Catherine Ashton) was appointed. The European Council therefore limited the discretion prescribed by the Lisbon Treaty for the HR/vP, stripping her of the advantage of the first mover and in practice providing her with 'guidelines' to follow. ${ }^{26}$ The presidency proposal brokered in the framework of COREPER II (the Comité des représentants permanents, Committee of Permanent Representatives - in this case, heads of mission) sets out inter alia the EEAs's legal status, scope, financing, staff delegations and the authority of the HR.

Through the negotiation process that started in the European Convention and resulted in the Lisbon Treaty and the Council's decision establishing the EEAS, the EU member states sketched out the scope of EEAS activity, outlined the instruments to be used by the EEAS and set the procedures that the EEAS was mandated to follow. Analysis of ex-ante control points to the restrictive administrative procedures that the member states apply in order to control the

\footnotetext{
24 Article 24(1) TEU.

25 Michael E. Smith, 'The European External Action Service and the Security-Development Nexus: Organizing for Effectiveness or Incoherence?' Journal of European Public Policy, vol. 20, no. 9 (2013), pp. 1299-1315.

26 Leendert Erkelens and Steven Blockmans, 'Setting Up the European External Action Service: An Act of Institutional Balance', European Constitutional Law Review, vol. 8, no. 2 (2012), pp. 246-279.
} 
EEAS. Although these procedures play a significant role in keeping the agent in line with its mandate, they do not provide sufficient grounds to combat possible opportunistic behaviour by an agent. Moreover, the sensitivity of foreign policy and the changing strategic political environment, in addition to lack of guarantees that the EEAS will actually follow its contractual obligations and not engage in opportunistic behaviour, make the creation and application of ex-post control mechanisms a logical choice.

\section{Ex-Post Control of the EEAS}

\section{Police Patrol}

Police patrol oversight refers to the active monitoring of an agent directly by the principal, with the purpose of identifying agency violations of the goals that are inherent in the contractual relationship between principal and agent. Monitoring of the agency's activity by the principal is carried out on a regular basis. However, police patrol involves the principal's active participation and therefore comes with a high cost. ${ }^{27}$ The member state principals use the European Council, the Foreign Affairs Council, the Committee of Permanent Representatives (CORE PER II), the Political and Security Committee (PSC) and the CFSP-related Council working groups as forums for monitoring and controlling the EEAS's action in EU foreign policy decision-making. An EEAS official shared: "The member states assume that we should think what they think and my colleagues also often ask: "What would the member states think?"'28

Through the enactment of the Treaty of Lisbon, the European Council was designated as an EU institution with a permanent President elected for two and a half years, renewable once. In practice, the European Council became a central player in the EU's external action, especially by setting the guidelines of EU foreign policy. ${ }^{29}$ The member states are represented in the European Council through their heads of state and government. The HR/vP participates in the European Council without being its member.

The Lisbon Treaty divided the Council into the General Affairs Council (GAC) and the Foreign Affairs Council (FAC). The FAC conceptualizes the

27 Mathew McCubbins and Thomas Schwartz, 'Congressional Oversight Overlooked: Police Patrols versus Fire Alarms', in Mathew McCubbins and Terry Sullivan (eds), Congress: Structure and policy (New York: Cambridge University Press, 1978), p. 427.

28 Interview, August 2014.

29 Niklas Helwig, Paul Ivan and Hrant Kostanyan, The New EU Foreign Policy Architecture: Reviewing the First Two Years of the EEAS (Brussels: Centre for European Policy Studies, 2013), pp. 18-20. 
EU's external action based on the guidelines set by the European Council, and ensures the consistency of EU actions. ${ }^{30}$ Although the HR/VP chairs the FAC meetings, prepares the agenda, presents the draft conclusions and shares the FAC's findings with the press, she is not a member of the Council and in practice conducts the CFSP and the CSDP according to the mandates granted by the member states. ${ }^{31}$ Theoretically, the HR/VP is charged with managing the agenda of the FAC. However, in practice the EU member states' foreign ministers pull the strings. For example, in 2012 the United Kingdom managed to put Pakistan on the agenda, France inserted issues related to Sahel, and the United Kingdom and Denmark prioritized anti-piracy measures. ${ }^{32}$ The new construct therefore puts the HR/VP and the EEAS in a functionally weak position, with no tools to counter the transition of member state-driven priorities onto the FAC agenda.

COREPER II comprises EU member states' ambassadors working on political, commercial, economic and institutional matters and preparing the FAC meeting. In contrast to the FAC, PSC and CFSP-related groups, COREPER II is not chaired by the HR/VP or the EEAS, but instead by the Council's rotating presidency. An EEAS official highlighted in an interview the consequences of this arrangement: 'For example, the summits are prepared by the EEAS in different working groups, but then the final discussion is in COREPER, chaired by the rotating presidency, which might not have great interest in that particular summit or in that particular agenda. ${ }^{33}$ Although the EEAS currently participates in COREPER II meetings through a member of a corporate board, COREPER II ambassadors often sideline the HR/VP and the EEAS. The ambassadors hold working dinners up to five times a week. They meet for coffee and lunch breaks. Besides formal meetings, they also meet in smaller groups to resolve differences. ${ }^{34}$

The PSC, which is responsible for monitoring issues relating to CFSP/CSDP, has been gaining in importance in preparing the EU's foreign policy dossiers and has become an actor in its own right. Although COREPER II has the competence to approve issues that were agreed in the PSC, its agenda is so heavy that it instead mostly ends up approving the decisions that are made by

\footnotetext{
30 Art. 16(6) TEU.

31 Art. 16(6) TEU.

32 Sophie Vanhoonacker and Karolina Pomorska, 'The European External Action Service and agenda-setting in European foreign policy', Journal of European Public Policy vol. 20, no. 9 (2013), pp. 1316-1331.

33 Interview, July 2015.

34 Mai'a K. Davis Cross, 'Building a European Diplomacy: Recruitment and Training to the EEAs', European Foreign Affairs Review, vol. 16, no. 4 (2011), pp. $45^{2}$.
} 
the PSC. ${ }^{35}$ Although the EEAS chairs the PSC, post-Lisbon modifications mean that its discretion has remained limited. The EEAs has not been able to resist the member states putting their priorities on the PSC's agenda. The EEAS's failure to prevent the PSC trip to Moldova and Ukraine is but one example. ${ }^{36}$

Post-Lisbon arrangements not only changed the chairs of the FAC and the PSC, but also altered the chairmanship of the Council working groups that are related to the CFSP. Currently, the EEAS replaces the rotating presidency in chairing sixteen working groups. ${ }^{37}$ Formally, the working group chairpersons appointed from the EEAS answer to the PSC chair and the HR/vP. They are responsible for organizing the meetings and determining the agenda within the group. However, a chairperson explained the limits of his agenda-setting powers by posing a rhetorical question: 'Formally I can say no to a member state about putting an issue on the agenda, but would it be in my interest?'38 Therefore, the EU member states control the EEAS in the Council working groups, both through their formal decision-making rights and through informally influencing the agenda-setting competence of the chair.

\section{Horizontal Checks vis-à-vis the EEAS}

The principal may establish several agencies with conflicting incentives that may well check each other through competition for the reasons of their survival or competence maximization. Since the resources are limited in a given institutional framework, rational agents compete, which creates indirect mechanisms of control, a form of mutual restraint or "horizontal control",39 As stated above, the European Commission has tools to play the role of horizontal checks vis-à-vis the EEAs.

In theory, the HR's functions as the European Commission's Vice-President and head of the EEAS are the highest-level links between the Commission and the EEAS. In practice, however, a Commission official shared in an interview

35 Stephan Keukeleire and Jennifer MacNaughtan, The Foreign Policy of the European Union (Basingstoke: Palgrave Macmillan, 2008), pp. 76-77; and Ana E Juncos and Christopher Reynolds, 'The Political and Security Committee: Governing in the Shadow', European Foreign Affairs Review, vol. 12, no. 2 (2007), pp. 127-147; and interviews in 2011-2012.

36 Sophie Vanhoonacker and Karolina Pomorska, 'The European External Action Service and Agenda-setting in European Foreign Policy', Journal of European Public Policy, vol. 20, no. 9 (2013), pp. 1316-1331; and interviews in 2011-2012.

37 Helwig, Ivan and Kostanyan, The New EU Foreign Policy Architecture.

38 Interview, June 2011.

39 Nadia Klein, European Agents Out of Control? Delegation and Agency in the Civilianmilitary Crisis Management of the European Union, 1999-2008 (Baden-Baden: Nomos, 2010), p. 43 . 
that linking the EEAS and the Commission through the position of $\mathrm{HR} / \mathrm{VP}$ did not function well during the first HR/vP's tenure: 'Ashton was never really present as a VP of the Commission and therefore frankly also neglected the meetings of the group of the External Relation Commissioners. This is what [Federica] Mogherini [the current HR/vP] aims to change by focusing on her Commission's ve hat' ${ }^{40}$

During the establishment of the EEAs, the Commission made a number of successful attempts to curtail the powers of the HR/VP. When introducing the new Commission in November 2009, the President of the Commission separated the portfolio of the European Neighbourhood Policy (ENP) from the Relex Commissioner and added it to the responsibilities of the Commissioner for Enlargement. As a result, although the complete portfolio of the Relex Commissioner was supposed to be transferred to the HR/VP, responsibility for the ENP remained within the Commission, thus limiting the power of the HR/ VP in neighbourhood policy. In practice, this meant that the HR/VP shared competences on neighbourhood policy with the Neighbourhood Commissioner. ${ }^{41}$

In December 2010, staff from the European Commission's DG Relex ( 585 officials) and from parts of DG Development (93 officials) were transferred to the EEAS. Prior to the transfer, however, the European Commission made the second successful attempt at curtailment. The first College of Commissioners' formal meeting on 17 February 2010 decided to transfer staff of the DG Relex dealing with international climate-change negotiations to the Commission's new DG for Climate Action. The energy task force was moreover moved to the Commission's DG for Energy. The European Commission therefore prevented moving integral parts of the DG Relex staff to the EEAS, keeping them in the Commission, ${ }^{42}$ and thereby contradicting the spirit of the Lisbon Treaty. However, a Commission official countered during an interview: 'The argument can be played both ways. For example, why do you have people in the Russia divisions in the EEAS who are formally responsible for energy, when it is the Commission that deals with energy?'43

The Council's decision instructs the EEAS and the Commission services to consult each other in all aspects of EU external action with the exception of the CSDP, yet the interviews with staff of the EEAS and the Commission reveal tensions between the EEAS on the one hand and, inter alia, the Commission's

\footnotetext{
$40 \quad$ Interview, December 2014.

41 Hrant Kostanyan, 'Don't Fix What Ain't Broke: A German-led Proposal to Change How the Neighbourhood Policy Is Managed Is Misguided', European Voice (3 March 2013).

42 Erkelens and Blockmans, 'Setting Up the European External Action Service', pp. 250-251.

43 Interview, December 2014.
} 
DG DEVCo (Development and Cooperation), DG ELARG (Enlargement), DG ECHO (Humanitarian Aid and Civil Protection) and DG TRADE (Trade) on the other. ${ }^{44}$ The ongoing 'turf wars' between the EEAS and the European Commission are aggravated in cases where there are no clear instructions about which of the two has competence, about who should take the lead on what issue and at what stage? The 'Vademecum on Working Relations with the European External Action Service', which was produced by the SecretariatGeneral of the European Commission in January 2011, provided grounds for some sort of modus vivendi, yet it did not eliminate the tensions between the EEAS's relationship with the Commission DGs in areas such as humanitarian aid, development, enlargement, trade and the European neighbourhood. ${ }^{45}$

Despite the Lisbon Treaty's intention to bring more coherence to EU external action through the establishment of the new HR/VP post and the EEAs, in practice the division between development (dominated by the Commission) and security policy (dominated by the EEAS) was maintained. ${ }^{46}$ The HR/VP and the EEAS are charged with contributing the EU's external action instruments. However, the EU's development-related instruments (see more below) remain within the Commission's responsibility. ${ }^{47}$ It is yet to be seen whether the EEAS's 2013 review, the cluster system since 2014 with the new group of External Relations Commissioners under the chairmanship of the HR/VP and the creation of the DG for Neighbourhood and Enlargement Negotiations (NEAR) will facilitate improvement of the relationship between the EEAS and the European Commission.

\section{The European Parliament as an Outlier}

As a result of the post-Lisbon Treaty modifications in general and the establishment of the EEAS in particular, the European Parliament widened its powers in a number of areas of EU external action and vis-à-vis the EEAS. Elisabeth Wisniewski argues that because of the strong democratic profile of the European Parliament, as well as inter-institutional dynamics and constraints, the European Parliament managed to gain more power than the Lisbon Treaty

\footnotetext{
44 Interviews, 2011-2013.

45 Interviews, 2011-2013.

46 Smith, 'The European External Action Service and the Security-Development Nexus'.

47 Council of the European Union, 'Council Decision of 26 July 2010 Establishing the Organization and Functioning of the European External Action Service', Official Journal of the European Union (2010), L 201/30-40, art. 9(1).
} 
actually prescribes. ${ }^{48}$ Indeed, despite the fact that the Lisbon Treaty grants the European Parliament a mere consultative role in the establishment of the EEAS, the European Parliament has successfully used its co-decision powers on the EEAS's financial and staff regulations to acquire de facto co-decision power on establishing the organization and functioning of the EEAs. ${ }^{49}$ As a participant of the European Convention has stated: "The drafters of Lisbon going back to the European Convention Treaty did not see this coming. ${ }^{50}$ The European Parliament managed to become a full member of the so-called 'quadrilogues' (that is, the European Parliament, the High Representative, the Council and the Commission) that negotiated the decision establishing the EEAS.

The European Parliament has used the negotiations to solidify and increase its say, not only in issues such as the HR/VP's political accountability, but also in influencing the creation of the post of chief operating officer of the EEAS, the balance of geographic and gender representation within the EEAS staff, the exchange of views with the Heads of Delegations and the access to confidential information of the Members of the European Parliament (MEPs). ${ }^{51}$ Prior to adopting the decision to establish the EEAS, the European Parliament managed to secure two important documents: the 'Declaration by the High Representative on Political Accountability' (DPA); and the 'Statement by the HR in the Plenary of the European Parliament on the Basic Organization of the EEAS Central Administration' (sCA).

The MEPs succeeded in broadening the HR/vP's obligation to inform the European Parliament about the aspects of the CFSP before their adoption. ${ }^{52}$ The European Parliament's role in concluding the Eu's international agreements was also strengthened. However, unlike the agreements falling under community matters, the European Parliament's consent is still not required in CFSP areas. The European Parliament extended its supervisory role over the appointment of EU foreign policy actors (see below). In the budgetary sense, the EEAS was made accountable to the European Parliament (also see below). The European Parliament was also successful in its efforts to stress

48 Elisabeth Wisniewski, 'The Influence of the European Parliament on the European External Action Service', European Foreign Affairs Review, vol. 18 no. 1 (2013), pp. 81-102.

49 Wisniewski, 'The Influence of the European Parliament on the European External Action Service'; and Kolja Raube, 'The European External Action Service and the European Parliament', The Hague Journal of Diplomacy, vol. 7, no. 1 (2011), pp. 65-80; Interviews, May, June and July 2011.

50 Interview, May 2011.

$5^{1} \quad$ Raube, 'The European External Action Service and the European Parliament'.

$5^{2}$ Interviews, June-July 2011. 
the promotion of democracy and human rights as an important aspect of the EEAS's actions. A day before the European Parliament gave its approval to the decision establishing the EEAS, the HR/VP promised serious attention for democracy and human rights promotion. ${ }^{53}$ Replacement of the HR/VP in the plenary of the European Parliament remains a contentious issue and is likely to be reopened in the upcoming revision in 2015. Under the current arrangement, the HR/VP will be replaced either by the relevant Commissioner or by a representative of the rotating or trio presidency (that is, three successive presidencies working closely together).

Whereas the European Parliament has certainly increased its role in EU external action and the EEAS is somewhat accountable to MEPS, it cannot be considered to be a principal, since the European Parliament does not have the power to delegate to the EEAs. The European Parliament cannot be considered as a horizontal check vis-à-vis the EEAS, since it is not an 'executive' body and does not operate at the level of an agent implementing EU external action, but instead exercises a legislative, supervisory and budgetary role. The principal-agent framework therefore does not capture the role of the European Parliament.

\section{Controlling through Sanctions}

\section{Staff}

Principals may use their power of appointment — namely, to appoint, dismiss or refuse to reappoint agency personnel - as a tool to sanction agents. The applicability of the power of appointments as a control tool by the principal is conditioned by the rules governing the contractual relationship between the agent and the principal. In some cases, the principal is in a good position to use the power of appointment as a tool to control agency activity. By contrast, in other cases, when an agent has to ensure the credibility of the principal's commitments, the appointing powers of the principal are reduced to maximize the independence of the agency's activity. ${ }^{54}$

In the EU structure, the option of using the power of appointment by the member-state principals to control $\mathrm{EU}$ agents varies across institutions and functions. Although the HR/vP is consecrated as 'the Appointing Authority', the principals' power over EEAS staffing is a major controlling tool. In the early

$53 \mathrm{HR} / \mathrm{VP}$, 'Speech by High Representative Catherine Ashton to the European Parliament on the Creation of the European External Action Service', Strasbourg (7 July 2010).

Pollack, The Engines of European Integration, p. 45 . 
days of the EEAS, the EU member states aimed to establish control of the service, in particular through securing key positions for their representatives.

The HR/VP is appointed and can also be fired by the European Council in agreement with the Commission President. The H R must then be approved as a VP of the Commission with the rest of the College by the European Parliament. The EU member states insisted on having at least one-third of the EEAS coming from the member states' national diplomatic services. An extra motivating factor for the United Kingdom and France in agreeing to the establishment of the EEAS was the calculation that they would be able to dominate Eu foreign policy by sending their highly capable diplomats to the EEAS. ${ }^{55}$

The relevant Commission and Council Secretariat staff were transferred to the EEAS immediately, but appointments from the member states' domestic diplomatic services progressed slowly. Filling the EEAS appointments illustrates competition between the EU member states in aiming to control the EEAS by having their national representatives in key positions. In February 2010, France and Germany expressed discontent about Catherine Ashton's reliance on British officials in her cabinet and in the EEAS working groups. Paris and Berlin interpreted this as an attempt to secure London's long-term influence over EU foreign policy. ${ }^{56}$ France initially resisted the transfer of the Crisis Management Planning Directorate (CM PD) from the Council Secretariat to the EEAS. However, France ultimately agreed, after making a deal with Finland and winning the appointment of a French national, Claude-France Arnould, as head of the CMPD. Berlin and Paris also agreed that Germany would have the position of Deputy Secretary-General for EEAs Political Affairs (Helga Schmid), while France would appoint the new Secretary-General of the Council. ${ }^{57}$ France also secured the position of Secretary-General of the EEAS and Poland's Maciej Popowski was appointed as a Deputy Secretary-General of the EEAS.

In 2011, more than half of the corporate board and management positions in the EEAS headquarters, as well as one-third of the management positions in the delegations, went to the EU member states' diplomats. ${ }^{58}$ Moreover, sixteen out of the 25 vacant ambassadorial positions were occupied by member-state diplomats; seven by those coming from the EEAs; and only two by

$55 \quad$ Kluth and Pilegaard, 'The Making of the Eu's External Action Service'.

56 Ian Traynor, 'Germany and France Dispute Lady Ashton's "Excessive” Eu Powers', The Guardian (February 2010).

57 Smith, 'The European External Action Service and the Security-Development Nexus'.

$58 \mathrm{HR} / \mathrm{vP}$, Report by the High Representative to the European Parliament, the Council and the Commission (Brussels: EEAs, 22 December 2011). 
European Commission representatives, although the Commission received the right to consent to the 'list of candidates' to be appointed as the heads of EU delegations. ${ }^{59}$ Many important ambassadorial positions - such as those in China, Brazil, Japan, Turkey and the United Nations - were given to national diplomats. ${ }^{60}$ Already at the end of 2011, 19 per cent of the service originated from EU national diplomatic services and most of these diplomats occupied senior positions. It is therefore not surprising that some EEAS officials originating from the institutions thought that candidates from member-state diplomatic services had benefited from the lobbying by their capitals. ${ }^{61}$ The member states' position was also strengthened legally, since staff regulations allowed the HR/VP to give priority to national diplomats until 30 June 2013. An EEAS official confirmed in an August 2015 interview that: 'The memberstate diplomats' distribution is disproportionately on the higher echelons of the EEAS, both in headquarters and the EU delegations'.62

The European Parliament also battled to widen its supervisory role over the EU's foreign policy actors. The HR's appointment and accountability to the European Parliament is linked to its double-hatted nature. Although the European Parliament can reject the appointment of the HR as a VP by not giving its consent, it is less clear how the European Parliament can hold other EU high-level officials accountable. The European Parliament's Committee on Foreign Affairs (AFET) hears the EU Special Representatives and the Heads of Delegation after their appointment, but before they are dispatched to the third countries. Therefore, the European Parliament's consent is not required for their appointments. ${ }^{63}$ Although a number of MEPs insisted on public hearings for the Heads of Delegation prior to their dispatch, this stipulation was rejected by the HR/VP. ${ }^{64}$ After a struggle between the HR/VP and MEPS on the format of the hearings, the controversy appears to have been solved in favour of holding an exchange of views in camera.

59 Council of the European Union, 'Regulation of the European Parliament and the Council amending the Staff Regulations of Officials of the European Communities and the Conditions of Employment of Other Servants of those Communities' (2010), PE-CONS 52/10, Art. 95(2).

6o Staffan Hemra, Thomas Raines and Richard Whitman, A Diplomatic Entrepreneur: Making the Most of the European External Action Service, Chatham House Report (London: RIIA, 2011), p. 8.

61 Juncos and Pomorska, 'In the Face of Adversity', p. 1339.

62 Interview, August 2015.

63 Raube, 'The European External Action Service and the European Parliament', p. 69.

64 'Ashton Eases through Parliament Hearing', Euractiv (12 January 2010). 


\section{Financing}

The ability of the principal to cut an agent's funding offers the possibility to sanction the opportunistic behaviour of an agent. ${ }^{65}$ However, making budget cuts often comes with adverse side effects for the principal, thus decreasing the credibility of the threat. The principal needs its agents to be functional in order for the agents to deliver the outcomes sought by the principal. An agent will not be able to accomplish the desired results if it is denied its budget. ${ }^{66}$ Moreover, in the EU structure, cutting the Commission's budget for policies such as agriculture or cohesion funds will have serious issues for the member states' domestic constituencies and will complicate the re-election campaigns of national politicians of affected states.

Prior to the establishment of the EEAS, the member states insisted that the EEAS operate with a view to 'budget neutrality'. Although the EEAS was given more responsibilities than its predecessors (DG Relex and the Council Secretariat, etc.) combined, any attempt to increase the budget met the resistance of some EU member states. The United Kingdom leads in its strong opposition to a budgetary increase for the EEAS. In May 2011, the HR/VP requested a $€ 26.9$ million increase in the 2012 budget for the EEAS. The request was followed by British Minister for Europe David Lidington's criticism: 'I think that they have got to get real as far as the budget is concerned. This 5.8 per cent that they're asking for is somewhat ludicrous'.67 In 2013, the UK House of Lords' European Union Sub-Committee on External Affairs published a report insisting that the EEAs's budget neutrality be prioritized. ${ }^{68}$

The European Commission also plays an important role in budgetary matters. The EEAS prepares proposals such as country allocations, country and regional strategic papers, and national and regional indicative programmes. ${ }^{69}$ However, the European Neighbourhood Instrument $(\mathrm{ENI})^{70}$ is conducted under the responsibility of the Neighbourhood Commissioner, and the Development Cooperation Instrument (DCI) and the European Development

\footnotetext{
65 Pollack, The Engines of European Integration, p. 43.

66 Terry M. Moe, 'The Politics of Structural Choice: Towards a Theory of Public Bureaucracy', in Oliver E. Williamson (ed.), Organization Theory: From Chester Barnard to the Present and Beyond (Oxford: Oxford University Press, 1990), pp. 116-153.

67 Quoted in Andrew Rettman, 'Uk Attacks Ashton over "Ludicrous" Budget Proposal', EUobserver (24 May 2011).

68 House of Lords' European Union Committee, '11th Report of Session 2012-2013: The EU's External Action Service Report' (London: House of Lords, 19 March 2013).

69 Interview, July 2011.

$70 \quad$ Formerly the European Neighbourhood and Partnership Instrument (EN PI).
} 
Fund $(\mathrm{EDF})^{71}$ are the responsibility of the Development Commissioner. ${ }^{72}$ Other external instruments, such as the Instrument for Stability or civilian aspects of the CFSP (but not expenditure of the CSDP), are also funded from the community budget. ${ }^{73}$ The EEAS also shares with the European Commission the control over the European Instrument for Democracy and Human Rights. ${ }^{74}$ The Commission therefore still controls a large bulk of foreign policy expenditure, thus limiting the discretion of the EEAS.

As well as the EU member states and the European Commission, also the European Parliament acquired strong budgetary authority over the EEAS. The European Parliament successfully insisted on recognition of the EEAS as the equivalent of an institution in budgetary matters. The intergovernmental budget line for the EEAS was rejected and the EEAS is fully funded under the community budget. Like the rest of the EU institutions, the EEAS therefore has its own budget section and acts within the limits set by the financial regulations applicable to the EU general budget. In practice, this means that the EEAS's budget is subject to the discharge procedure, similar to other Eu institutions, and is therefore accountable to the European Parliament.

\section{Agency Revision}

The relations between a principal and an agent are dynamic; delegation is an ongoing process. The experiences of each delegation are noted down and their benefits and failures are decisive in issuing further transfers of authority. ${ }^{75}$ Revising the mandate of a given agent is a logical continuation of the delegation, since, although both principal and agent are regarded as rational players, they do not act on the basis of full information but on the information available. The member-state principal realizes that the agent, once created, may exploit its autonomy over time; however, EU member states are not able to predict the exact shape of the developments. Moreover, changes in the number of principals over a certain period of time also influence the strategic milieu. ${ }^{76}$ On the one hand, EU member states may try to stop the agent's exploitation of

\footnotetext{
71 The EDF is outside of the Eu budget.

72 Kamil Zwolski, 'The EU and a Holistic Security Approach after Lisbon: Competing Norms and the Power of the Dominant Discourse', Journal of European Public Policy, vol. 19, no. 7 (2012), pp. 988-1005.

73 Raube, 'The European External Action Service and the European Parliament', p. 69.

74 Smith, 'The European External Action Service and the Security-Development Nexus', pp. 1309 .

75 Jonas Tallberg, 'Delegation to Supranational Institutions: Why, How, and with What Consequences?', West European Politics, vol. 25, no. 1 (2002), pp. 27-28.

76 Tallberg, 'Delegation to Supranational Institutions', p. 37.
} 
its autonomy through agency revision. On the other hand, EU member-state governments may boost the competences of an agent in order to provide it with extra tools to maximize the possibility of achieving their objectives.

The agent's mandate can be revised through treaty change and Council decisions. Modifying an agent's mandate through treaties has proved to be the most effective yet most complicated option. Mark Pollack calls it the 'nuclear option' and an ultimate threat against the agent by the principal. ${ }^{77}$ Treaty revision, however, is a fairly complicated process that engages the Council, the IGCS and supranational institutions and requires agreement by unanimity and ratification by each EU member state. The failure of the Treaty establishing a Constitution for Europe (TCE) and the long road to enactment of the Lisbon Treaty are but examples that illustrate the complexity of the process. Nevertheless, the above-mentioned constraints have not forced the EU member states to abandon the treaty-revision option. Such a revision was successfully carried out eight times in the last five decades, although each case had its own rationale, met different kinds of challenges and overcame them in rather innovative ways.

Devising Council decisions where the details of the agency mandate are outlined is yet another option for agency revision. Since Council decisions are not part of a treaty, the legislative principal has the 'power to override agency behaviour through new legislation and to revise the administrative procedures laid down in the agent's mandate,78 without resorting to the long and exhaustive 'nuclear option'. Moreover, a number of the European Commission's executive powers that are established by Council regulations have an 'expiration date'. The existence of a fixed expiration date within the agent's mandate provides the principal with the possibility of avoiding a 'default condition,' ${ }^{79}$ since the agent's mandate has to be extended and is automatically open to further revisions.

The EEAS is a product of consequent delegation and agency revisions through treaty-making and Council decisions. The EU member states have revised the European Commission's and Council Secretariat's mandates through treaty changes and Council decisions and have created, inter alia, the post of the HR/VP and the EEAS. In order to make the EEAS operational, the

77 Mark A. Pollack, 'Delegation, Agency and Agenda-Setting in the European Community', International Organization, vol. 51, no. 1 (1997), p. 118.

78 Pollack, 'Delegation, Agency and Agenda-Setting in the European Community', p. 109.

79 Fritz W. Scharpf, 'The Joint-Decision Trap: Lessons from German Federalism and European Integration', Public Administration, vol. 66, no. 3 (1988), pp. 239-278. 
'quadrilogues' have interpreted and elaborated the treaty provisions in the Council decisions.

The Council decision that established the EEAS identified 2014 as the timeframe to revise the organization and functioning of the EEAs based on the HR/ VP. ${ }^{80}$ This revision, however, was postponed until 2015. Specifying the date for revision of the EEAS decision plays the role of an 'expiration date' for the first stage of the contractual relationship between the EU member states as principal and the EEAS as agent. This excludes the 'default condition', since the EEAs's mandate is automatically open for modification. As far as formal decision-making goes, the member states - in the Council framework — retain the right to revise their decision, with the European Commission consenting and the European Parliament having a consultative role. The EU member states will acquire the opportunity to revise the EEAs's mandate, but this can only be assessed after 2015 .

\section{Conclusions}

The EU member states have actively participated in every stage of the EEAs's creation and activity. By revising the European Commission's mandate and transferring some functions that were formerly performed by the Council Secretariat, the EU member states as the principal have been the driving force behind the EEAs. Through ex-ante administrative procedures, the EU member states defined the framework of the EEAs's actions, outlined the instruments that it is expected to implement and described the procedures that it has to follow.

The EEAS is ex-post monitored and controlled through so-called 'police patrol' and horizontal checks. The EU member states 'police patrol' the EEAS through the European Council, FAC, COREPER, the PSC and the CFSP-related Council working groups. The HR/VP and the EEAS chair the FAC, PSC and a number of relevant working groups. Conversely, COREPER is chaired by the rotating presidency. Analysis of the decision-making in the Council structures reveals that the member states' representatives are effectively in charge of the EU foreign-policy decision-making process in general and the EEAS in particular.

The EEAS is tied to the European Commission on multiple levels, starting from the services up to the HR/VP. The linkages between the Commission DGs

8o Council of the European Union, 'Council Decision of 26 July 2010 Establishing the Organization and Functioning of the European External Action Service', art. 13(3). 
in dealing with the European Union's external relations and the EEAS often result in tensions that serve the purpose of horizontal checks. The European Parliament managed to use its co-decision powers in financial and staff regulation to acquire a role of co-decider in the decision establishing the EEAS, although in the latter case the Lisbon Treaty ascribes a merely consultative role to the European Parliament. The European Parliament was successful in extending its political control over the HR/VP and the EEAS.

The ex-post monitoring of the EEAS is complemented by the mechanism of sanctions, such as appointments, financing and revision of the mandate that the EU member states (can) implement to control the EEAs's activities. In terms of personnel, the EU member states have the right to hire and fire the HR/VP. By inserting their representative in the service, the member states aim to retain strong control over EU foreign policy. The European Commission receives the right to approve the HR's appointment and the European Parliament gives consent to the HR as a VP of the European Commission with the rest of the College of Commissioners. EU member states, along with the European Parliament, decide on the budget of the EEAS, which is presented by the European Commission after receiving the HR/VP's estimate of the EEAs's expenses accompanied by a report on the staff of the EEAS in both the central administration and the delegations. Before submitting the expenses to the European Commission, the $\mathrm{H}$ R/vP holds consultations with the Commissioners for Development, Neighbourhood and Humanitarian Aid policies in order to estimate the administrative expenditure of the EEAS.

The EEAs has been established through treaty-making and Council decisions that have revised the Commission's and the Council Secretariat's mandate, transferring some of their departments and staff to the EEAS along with EU member states' diplomats. Based on Council decisions, the EEAs's mandate will continue to be revised. The HR/vP presented a review to the Council, the European Parliament and the European Commission in 2013. Formally, the EU member states enjoy the right to revise their decision establishing the EEAS after receiving the consent of the European Commission and consulting the European Parliament, both of which are expected to defend and expand their 'turf'.

Adding to the principal-agent literature, this case confirms that an agent that is delegated competences in a politically sensitive issue-area such as foreign policy - a central aspect of the nation-state principal's sovereignty is tightly controlled by the delegating principal and did exhibit unwarranted opportunistic behaviour in the early years of its existence. Moreover, the analysis finds that the principal-agent framework is suitable for evaluating the member states' control over the EEAs, as well as the horizontal checks that are 
facilitated by the European Commission. However, the model falls short on conceptualizing the role of the European Parliament, which remains an outlier to the principal-agent relationship.

By analysing the control mechanisms, this article concludes that the EU member states currently effectively control the EEAS. However, because of the dynamic challenges that the $\mathrm{EU}$ is facing in its foreign policy, it remains to be seen whether the EEAS will be able to increase its autonomy and room for manoeuvre vis-à-vis the member states over time and on certain issues and geographical areas. Finally, the EU's internal institutional dynamics might equally affect the EEAs's discretion in the future, with the European Commission and/ or the European Parliament curtailing or supporting greater autonomy of the EEAS.

Hrant Kostanyan is a Researcher at CEPS 'Europe in the World' unit, a Senior Key Expert at the College of Europe Natolin, and an Associate Fellow at the Centre for EU Studies (CEUS) in the Department of Political Science at Ghent University, Belgium. His research focuses on EU institutions and decision-making, primarily on the EEAS, the ENP and the EU's relations with Eastern neighbours and Russia, and he has taught courses on European Union decision-making and inter-institutional relations, as well as the EU'S relations with the post-Soviet space. Dr Kostanyan is a reviewer and editorial board member of a number of academic journals, as well as co-editor of CEPS European Neighbourhood Watch monthly newsletter. He has published extensively on EU decision-making and external policies. 